\title{
ORIENTASI PEMIKIRAN KEAGAMAAN MAHASISWA
}

\section{H. Abd. Kadir Ahmad}

\section{A. PENDAHULUAN}

Secara common sense, adagejalapeningkatan kesadaran mahasiswa terhadap kehidupan keagamaan. Hal itu boleh jadi, merupakan salah satu sisi dari terjadinya degradasi kiprah mahasiswa dalam masyarakat akibat adanya restrukturisasi dan semboyan back to campus, pasca tahun 70an. Di sisi lain, boleh jadi gejala itu sebagai bagian dari ekskalasi kesadaran beragama yang secara umum terjadi dalam masyarakat. Yang pasti, mahasiswa menemukan dimensi bam dalam kehidupannya sebagai moral force, yang lebih berorientasi kc dimensi pergumulan religius. Gejala itu dapat dengan mudah ditemukan dalam banyak hal. Masjid-masjid kampus sarat dengan kegiatan keagamaan baik pengajian, pcngkajian maupun aktivitas belajar agama dalam bentuk lain. Dalam hal yang lebih transparan, mahasiswa wanita cenderung memperlihatkan kesadaran keberagamaan secara formal dalam bentuk pemakaian busana berciri khas islami.

Suatu gagasan mahasiswa yang cukup keras gaunnya kelihatan ketika sekelompok aktivis dari Universitas Brawijaya Malang melopori diadakannya SimposiumJTendekiawan Muslim se Indonesia (ICMI), tahun 1990. Meski sekali lagi mahasiswa memperlihatkan jati dirinya sebagai penggagas dan pencetus ketimbang sebagai pelaku sejarah, mahasiswa merupakan asset besar dalam proses pembentukan watak manusia Indonesia.

Sayang sekali, gaung dari aktivitas dan anatomi keagamaan mereka belum banyak terungkap, khususnya melalui ekspos penelitian. Berusaha mengungkap dimensi tertentu dari kondisi tersebut, suatu penelitian kemudian dilakukan dengan mengambil Universitas Muslim Indonesia Ujung Pandang sebagai sasaran. Bertemakan Oricntasi Pemikiran Keagamaan Mahasiswa, penelitian ini dilakukan sebagai salah satu paketpenelitian dari Balai Penelitian Lektur Keagamaan Ujung Pandang.

B. Kasus Universitas Muslim Indonesia

Universitas Muslim Indonesia, selanjutnya disingkatUMI,didirikan padatanggal22 Syawal 1373 H/23 Juni 1954 di bawah Yayasan Badan Wakaf UMI. UMI kini membina 10 Fakultas dengan mahasiswa sekitar 17 ribu orang, seperti tabel di bawah ini;

\section{FAKULTAS DAN MAHASISWA UMI 1990}

\begin{tabular}{c|l|l|c}
\hline NO. & FAKULTAS & \multicolumn{1}{|c}{ STATUS } & MAHASISWA \\
\hline 1. & Ushuluddin & $\begin{array}{l}\text { disamakan } \\
\text { proses di- }\end{array}$ & 522 \\
2. & Ekonomi & samakan & 5.431 \\
& & diakui & 4.184 \\
3. & Hukum & diakui & 1.856 \\
4. & Teknik & 613 \\
5. & Syari'ah & diakui & 418 \\
6. & Sastra & terdaftar & 1.680 \\
7. & Pertanian & terdaftar & 939 \\
8. & Perikanan & terdaftar & 805 \\
9. & Teknologi & terdaftar & 290 \\
10. & Industri & Tarbiyah & 16.728 \\
\hline
\end{tabular}

Sekitar 300 mahasiswa dijaring dalam penelitian ini melalui angket. Hasilnya menunjukkan fenomena yang secara umum di kedepankan dalam deskripsi kualitatif.

Kegiatan-kegiatan mahasiswa di bidang keagamaan umumnya dilatarbelakangi oleh 
kenyataan bah wa pelaksanaan ibadah pokok yang diwajibkan dalam Islam ternyata belum didukung pemenuhan psiko-motoris-nya oleh pengetahuan yang memadai melalui jenjang pendidikan sebelumnya, terutama karena kondisi belajar agama yang kurang kondusif dalam proses belajar mengajar.

Karena itu sekitar $76 \%$ responden berusaha melakukan upaya belajar sampingan, baik belajar sendiri dengan membaca buku-buku agama, maupun melalui kcgialan majelis ta'lim yang dilakukan oleh organisasi intra sekolah, organisasi ekstra, atau oleh masyarakat. Gejala tersebut semakin kuat di perguruan tinggi. Dari upaya-upaya remedial tersebut, mahasiswa ternyata lebih menggandrungi proses belajar mengajar yang disajikan secara dialogis. Bentuk-bentuk forum dialog kelompok diskusi banyak muncul untuk memenuhi hasrat tersebut.

Forum-forum yang muncul mengambil nama-nama ideal baik tokoh maupun peristiwa dalam sejarah Islam, seperti al-Ghiffary (Fakultas Pertanian), Darul ar-qam (Fak.Tarbiyah), Ashabul Kahfy (lintas universitas), Khaerunnisa (mahasiswa wanita tingkat universitas), Ulul al-bab (khusus mahasiswa tingkat universitas). Nama-nama tersebut hanyalah kelompok-kelompok yang cukup vokal. Masih banyak kelompok yang berafiliasi di bawah fakultas baik intra maupun ekstra.

Kelompok diskusi keagamaar>--3£plrti itu memperlihatkan coraknya masing-masing. Fokus dan tema pendalaman bervariasi baik menurut fakultas maupun menurut faham keagamaan yang mendominasi kelompok itu. Kelompok studi yang beraviliasi ke fakultas mengarahkan pengkajian pada Islam dalam kaitan dengan disiplin ilmu yang digeluti, meski hal ini tidak berlaku umum.

Semcntara kelompok diskusi tingkat univer- sitas dan lintas universitas lebih berorientasi ke pengkajian agama secara umum dikatakan dengan masalah-masalah aktual, baik di lihat dari kepentingan jamaah/pesertanya maupun dilihat dari tantangan yang dihadapi ummat Islam. Meski tidak ada kelompok yang secara gamblang menetapkan afiliasinya terhadap suatu orga-nisasi ekstra seperti Pergerakan Mahasiswa Islam Indonesia (PMII), Himpunan Mahasiswa Islam (HMI), dan Ikatan Mahasiswa Muhammadyah (IMM), karakteristik forum sering tidak dapat dipisahkan dari ikatan primordial tersebut.

Dilihat dari program pembinaan dan vokalitasnya terhadap masalah-masalah sekitar, forum-forum studi ternyata lebih efektif dan vokal daripada organisasi intra, seperti BPM dan SEMA.

Bidang-bidang agama (Islam) yang digeluti berporos kepada kebutuhan dasar ke-Islam-an yaitu Aqidah/tauhid dan ibadah/fiqhi/Syari'ah, Sejarah Islam, Tafsir, Hadits, Tasauf. Hal ini tampak dari buku-buku (lektur) yang mereka baca. Terdapat kecenderungan perbedaan arus pemikiran keagamaan antara aktivis organisasi/ forum dengan yang non-aktivis. Kelompok pertama cenderung melakukan ekspansi ke dalam pemikiran-pemikiran Islam kontekstual, lebih daripada pelajaran dasar agama, yang ternyata banyak digeluti kelompok kedua.

"'"Pcntingnya belajar Islam bukan hanya untuk memenuhi kebutuhan akan ibadah, seperti dikemukakan di atas. Lebih dari itu, ajaran Islam perlu di dalami justru karena Islam memang dibuluhkan dalam kehidupan sebagai pemberi arah (hudan) menuju harmonisasi hubungan an tar luntutan dunia dan akhirat (83\%). Dalam hubungan ini responden mengakui hanya Islamlah yang mampu memberikan kode hidup yang lengkap dan tertinggi. Namun demikian, pemeluk Islam haruslah bersikap tolerans ter- 
hadap sistem atau paham lainnya dalam pengertian hidup saling menghormati dan menghargai. Menurut responden loleransi antar umat beragama hanya dapat dilakukan manakala setiap pemeluknya tegas pada prinsip aqidahnya, dan bukan sebaliknya.

Kasus-kasus yang terkadang muncul sebagai masalah antar ummat beragama seperti kawin silang dan salah seorang pengikut suatu agama ikut beribadah dalam kelompok agama lain dinilai responden sebagai tidak wajar. Dalam keharusan sikap saling menghormati antar pemeluk agama, ternyata mahasiswa amat peka. Ketika pada suatu waktu (4 Nopember 1990) penulis melakukan Focus Group Discussion dengan Kelompok Studi Darul Arqam, mengambil tema "Refleksi Tentang Kasus Monitor" dengan berusaha mendckati masalahnya secara proporsional, ternyata forum tetap menganggap hal itu tidak perlu terjadi, karena merupakan salah satu bias dari kerukunan hidup beragama.

Menarik dikemukakan bahwa responden melihat adanya keprihatinan terhadap semakin beratnya tantangan yang dihadapi ummat Islam sekarang, khususnyadilihatdari konteks perkembangan zaman.

Sikap lain yang ditunjukkan responden adalah persepsinya tentang makna hidup. Menurut mereka, dalam kehidupan yang ideal dituntut adanya keseimbangan antara kemampuan beribadah dan bekerja keras (90\%). Dalam konteks ini, bekerja berartibukan untuk bekerja itu sendiri, akan telapi mengejar cita-cita lewat bekerja harus dipintal dengan etika dan moral. Tidak satu pun responden mentolerir cara-cara yang tidak etis dalam upaya mencapai tujuan, seperti ungkapan tujuan menghalalkan cara. Sebaliknya sifat jujur, benar, dan ikhlas merupakan atribut ideal yang seharusnya menjadi pegangan. Meski demikian, sikap mengikuti arus/kondisi cenderung menggejala dan menjebak secara kontorversial, seperti kasus-kasus menempuh cara-cara yang kurang fair dalam ujian. Dan anehnya, mereka tahu bahwa itu menyalahi norma. Disini muncul sikap pragmatisme yang sudah menggejala dan dapat merambat ke hal lain yang justru akan menggoyahkan prinsipprinsip ideal dan luhur.

Responden jugamenyadari bahwa banyaknya penyelewengan dan bias dari norma agama erat kaitannya dengan melemahnya sikap tegur sapa sosial atau kontrol sosial. Sebaliknya masyarakat semakin berwatak permisif dan cenderung ke'nafsi-nafsi". Padahal mereka tahu bahwa melakukan kontrol sosial adalah merupakan kewajiban (97\%). Derasnya pengaruh terhadap prilaku menyimpang khususnya bagi generasi muda sekarang, sehingga sebagian responden $(21 \%)$ berkesimpulan adanya penurunan kesadaran beragama di banding sebelumnya. Namun demikian, pada umumnya melihat perkembangan yang cukup menggembirakan dalam kehidupan beragama sekarang ini. Kelompok yang terakhir ini menunjuk hal-hal konvensional sebagai indikatornya, seperti semakin semaraknya rumah-rumah ibadah dikunjungi para jamaah, khususnya generasi muda, semakin besarnya perhatian pemerintah terhadap kehidupan beragama, banyaknya rumah ibadah dan lembaga pendidikan Islam, dan bertumbuhnya majelis-majelis ta'lim.

Yang pasti adalah bahwa tantangan yang dihadapi ummat Islam lebih berat sekarang ketimbang sebelumnya. Ancaman dari luar berupa ekses dari globalisasi kultural dengan segala ekscsnya bertemu dengan ancaman dari dalam berupa masaih cukup lemahnya kondisi sosial ekonomi basis massa Islam, yaitu kebodohan dan kcmiskinan. Termasuk sebagai ancaman, menurut responden adalah kecenderungan degradasi lingkungan hidup. 
Sepanjang yang dapat diperoleh dari pernyataan responden, terungkap beberapa potensi kritis ummat Islam yang dipandang mendesak untuk dibenahi. Masalah yang dominan melingkar pada domain sosio-ekonomis. Kesenjangan kaum agniya dengan kaum dhuafa perlu ditangani secara serius melalui pemanfaatan secara maksimal pranata zakat, infaq dan shadaqah. Di samping itu pola hidup konsumersitik dan hedonislik juga disoroti secara tajam, seakan jargon pola hidup hidup sederhana tidak lebih dari ungkapan verbalistik. Sama kritisnya dengan masalah ekonomi adalah kritis di bidang pendidikan. Perlu diperbaiki orientasi dalam sistem pendidikan ummat sesuai dengan kebutuhan. Walau ada kecenderungan pembatasan pembukaan lembaga pendidikan melalui mekanisme akreditasi, dengan segala konsekunsinya, responden melihat masih dibutuhkan peningkatan kuantitas di lembaga pendidikan terutama di desa-desa di samping memperbaiki kualitas lembaga yang sudah ada. (Bandingkan dengan potensi kritis ummat Islam oleh A.M.Saefuddin (dalam Amin Rais, 1986).

Ada kecenderungan mahasiswa mencairkan pola hubungan antar pengikul ormas yang relatif beku akibat pandangan berbeda dalam hal firqah pemahaman agama. Jika harus dipermasalahkan, sebaiknya tidak menjadi konsumsi umum, tetapi diberikan kepada ahlinya dalam majlis yang terbatas. Untuk itu perlu dikembangkan sikap saling menghargai, dan tidak memullakkan pandangan sendiri. Forum dialog lintas ormas perlu semakin digalakkan.

Dalam pada itu, dibutuhkan profil pemimpin umat yang mampu mengayomi kepentingan bersama. Ternyata profil ulama mendapat porsi lebih besar $(52 \%)$ dibanding cendekiawan mus$\lim (31 \%)$. Hal itu dikaitkan dengan kebutuhan akan pemimpin ummat yang berwibawa, kharismatik dan dapat menjadi panutan. Disebutkanlah sejumlah nama yang populer, seperti Buya Hamka (K.H. Zinuddin MZ, KH. Hasan Basri, K.H. Ahmad Dahlan, H. Qamariah, Prof. Harun Nasution, M. Natsir, Munawir Sazali, K.H. Ahmad Shiddiq, Nurcholis Majid, Agus Salim, Idham Khalid, Dr. Quraisy Syihab dan K.H. Kasim Nurseha. Nama-nama itu muncul ketika diminta kepada responden menuliskan lima orang tokoh Islam yang paling dikagumi. Tentu saja pemunculan tokoh-tokoh tersebut sangat relatif, sebab hanya dilihat dari keakrabannya" dengan responden atau intensitas pemunculannya sebagai muballiq, atau penulis buku, dan atau popularistasnya.

\section{B. Kesimpulan}

Dari uraian didepan, dapat dimengerti bahwa ternyata mahasiswa menyimpan nuansa tersendiri yang justru sangat kaya dalam hal kehidupan beragama baik dilihat dari bentukbentuk pelajarannya, dimensi-dimensi yang digel uti dan keluasan wawasan yang dicakupnya. $\mathrm{Hal}$ itu, tentu saja menarik untuk dikembangkan, melalui pengarahan teknik-teknik pembclajaran yang lebih sistimatis dilihat dari kaca mata kelckturan Islam. Hal itu penting untuk menjaga tertib berpikir mahasiswa dan mencegah timbulnya paham-paham sempalan yang boleh jadi dapat semakin merepotkan. 